\title{
Intersectionality in Feminist and Queer Movements
}

\section{Confronting Privileges}

Edited by Elizabeth Evans

and Éléonore Lépinard

First published 2020

ISBN: 978-0-367-25785-9 (hbk)

ISBN: 978-0-429-28985-9 (ebk)

\section{Chapter 12}

\section{Intersectional politics on domestic workers' rights}

The cases of Ecuador and Colombia

Daniela Cherubini, Giulia Garofalo Geymonat and Sabrina Marchetti

(CC BY-NC-ND 4.0) 


\title{
Intersectional politics on domestic workers' rights
}

\author{
The cases of Ecuador \\ and Colombia
}

\author{
Daniela Cherubini, Giulia Garofalo Geymonat \\ and Sabrina Marchetti
}

\section{Introduction}

This chapter focuses on organising for domestic workers' rights as a telling case in relation to the uses of intersectionality as a social movement strategy ${ }^{1}$ (Chun, Lipsitz, and Shin 2013; Evans 2016; Lapèrriere and Lépinard 2016). As we will show through the analysis that follows, this case represents an example of selforganising based on multiply-marginalised identities, which has been described in the introduction of this volume as a first possibility in the use of intersectionality in social movements.

We take the case of two domestic workers' organisations in Ecuador and Colombia and, through the analysis of their discourses and activities between 2011 and 2018 we explore the different 'intersectional politics' that these two collective actors have developed 'on the ground' with the aim of making sense of the specific experience of marginalisation lived by domestic workers, as well as building their collective identity, putting forward their claims, and dealing with other potentially converging social struggles that surround the promotion of domestic workers' rights - in particular, feminist, anti-racist, and labour struggles.

Throughout this analysis we propose a heuristic model for the application of intersectionality to the study of the collective action carried out by multiplymarginalised groups. In particular we use a multilevel approach which looks into (1) the collective identity of the organisations, (2) the claims, activities, and frames that they mobilise, and (3) the alliances they establish with institutional and noninstitutional actors in related fields. Such a multilevel reading allows us to show how in different aspects and moments of their mobilisations, the organisations under study can embrace different approaches to intersectionality, and their strategies and positioning in this field change when moving from discourses to actions, from compositions to claims, to address (or not) privileges and inequalities rooted in gender, class, and race relations.

In this chapter we illustrate our multilevel analysis of domestic workers' movements by offering a comparative study of two organisations mobilising for domestic workers' rights in Colombia and Ecuador, which have been 
chosen both for their visibility and for the impact of their actions at the national level. The study of these two organisations is part of a broader comparative study on the transformations of paid domestic workers' rights and conditions in Europe, Latin America, and Asia from 1950 to the present day. Local researchers $^{2}$ gathered data between April 2017 and March 2018, while the authors made ethnographic visits and conducted workshops between September 2017 and January 2018.

The analysis presented in this chapter is based primarily on a total of 46 qualitative in-depth interviews held in both countries with key informants including representatives from domestic workers' grassroots organisations, women's and feminist groups, ethnic minorities' organisations, trade unions and workers' organisations, human rights and non-governmental organisations, governmental and state actors, and international organisations (in particular the ILOInternational Labour Organization regional offices), as well as with academic experts. These interviews are complemented by written documents produced by organisations of domestic workers and other relevant actors and by ethnographic observations during meetings and workshops with local stakeholders. The analysis we propose does not aim to be representative of the complexity of the processes at stake, as we use an interpretative approach of the materials that are looked at as situated accounts produced in a particular context and time. Finally, we used statistical data gathered mainly from Population Censuses of 2005 (Colombia) and 2010 (Ecuador) describing the sociodemographic characteristics of people employed in paid domestic work.

In what follows we first provide a short review of the literature on intersectionality and social movements, indicating how our work may be seen as engaging with some of the open conceptual and methodological questions and empirical shortcomings in the current debate. In the next section we describe the composition of domestic workers' labour forces in Ecuador and Colombia, both of which largely show similar patterns of a strongly gendered and ethnicised labour force. In addition to this, we describe how both countries find themselves, since the late 2000 s, in a period of emergent mobilisation in the field, with the creation or strengthening of paid domestic workers' organisations, and pivotal legislative reforms - such as the ratification of the ILO Convention No. 189 - that are regarded as special achievements of the movements we discuss. Such a contextual analysis demonstrates the relative comparability of the two organisations ${ }^{3}$ that we take as case studies in the following of the chapter: ATHE - Asociación Trabajadoras de Hogar Ecuatorianas (Ecuadorian Domestic Workers' Association) and UTDC - Unión de Trabajadoras Domésticas de Colombia (Colombian Domestic Workers' Union). Our analysis of the organisations through intersectional lenses focuses on two at least partly distinct levels: on the one hand, we consider their composition and collective identity, and on the other hand, we look into their most important recent campaigns, taking into consideration the claims, actions, discursive frames, and alliances they mobilised. 


\section{Intersectionality in social movements}

As illustrated in the introduction to this book, in the last decades an expanding body of studies has drawn upon the concept of intersectionality as a critical tool to explore a vast array of political projects and social movements (Evans and Lépinard, this volume). Intersectionality has been used as an analytical tool to investigate social movements in relation to the construction of their collective identity (Carastathis 2013; Maddison and Partridge 2014; Okechukwu 2014), agendas, representation and recruitment strategies (Strolovitch 2007; Alberti, Holgate, and Tapia 2013), as well as the framing processes and cultural repertoires they adopt (Cruells López and Ruiz García 2014; Lépinard 2014; Okechukwu 2014), and the conflicts, coalitions, and alliances they establish (Ferree and Roth 1998; Cole 2008; Townsend-Bell 2011; Predelli and Halsaa 2012; Verloo 2013; Coley 2014; Rothman 2014). This literature suggests that intersectionality is an inspiring concept to be applied to a vast array of social movements - not limited to feminist movements - that can be understood, articulated, and used in different ways, for different purposes, and that may encounter various forms of resistance - to which correspond a variety of possible consequences for movements' struggles and constituencies. Several authors suggest that mapping the different uses, resistances, and outcomes of intersectionality 'on the ground' is a relevant task that deserves further elaboration (Townsend-Bell 2011; Bassel and Lépinard 2014; Evans 2016; Evans and Lépinard, this volume). There is no agreement, however, on how to carry out this analysis at the methodological level. Where should we look in order to understand the specific ways in which collective actors engage with intersectionality as a cognitive and political strategy to carry on their struggle? And crucially, how can we account for the dynamic and situated character of individual and collective actors' positioning processes, while carrying out this analysis?

This chapter engages with these questions by employing a multilevel intersectional approach to the study of social movements, separating the analysis into different levels - namely the collective identity of organisations; their claims, activities, and discursive frames; and the alliances they establish - without postulating a coherence in the way intersectionality takes place at each level.

In applying this analytical model, we pay special attention to how categories such as gender, race, and class convey different meanings and have different relative power in structuring domestic workers' struggle in different spaces, at different scales, and at different moments in time - thus drawing on the ideas of 'translocality,' 'transcalarity,' and 'transtemporality' of social divisions developed by Nira Yuval-Davis (2015) and Floya Anthias (2012). We show how intersectional identities are forged by different movements with different emphasis on gender, race, and class, we investigate how these intersectional identities are in turn translated into organisations' activities and claims directed to their members and to external actors, and finally we explore the ways in which the construction of alliances may imply downplaying or integrating the categories they emphasise in their collective identity-making. 
Finally, when looking at the empirical cases addressed so far by the literature on intersectionality in social movements, one can see that most studies concentrate on feminist movements, take place in Western contexts, and are developed on a national basis. Within this scenario, little attention is given to other kinds of women's movements that may not define themselves as feminist (Molyneux 2001), as it is often the case with women workers' movements (Cobble 2005) and in particular with movements for informal, precarious, and mostly female workforce, such as domestic workers (relevant exceptions, among others, are Alberti et al. 2013; Bernardino-Costa 2014). Our chapter addresses these shortcomings by looking at the kind of women's labour movement that is rarely researched in this literature, focusing on non-Western contexts, and using a large comparative analysis.

\section{The international movement for domestic workers' rights and the case of Ecuador and Colombia}

At the global level, domestic workers have been seen as the quintessential example of low-skilled, low-valued, precarious, hidden, and unorganised labourers (Boris and Fish 2014; Sarti 2007; Schwenken 2016). They are partly or fully excluded from labour laws and protections in several countries, and they usually belong to the most impoverished and socially stigmatised groups in each context: migrants, low-caste people, black and indigenous women, and so on, depending on the context. Moreover, their situation across countries has increasingly been impacted by the multidimensional transformations induced by globalisation, such as the intensification of international migration, reorganisation of social classes, the urbanisation of rural and indigenous populations, and changes in gender norms, lifestyles, household organisation, and welfare regimes.

In recent decades, the condition of these workers has become an object of general concern, and several local and global actors have undertaken actions to promote rights and better working conditions in the sector. Among these actors are international organisations such as the ILO and the UN Commission on the Status of Women, as well as NGOs, trade unions, and domestic workers' organisations active at national, regional, and transnational levels (Fish 2017; Marchetti and Garofalo Geymonat 2017). The increased relevance of domestic work as a global governance issue and as a matter of contention parallels the increasing visibility and mobilisation of this category of workers, the strengthening of their organisations and campaigns, and the improvement of normative frameworks that influence their conditions. Key examples - at the transnational level - are the promulgation of the ILO 'Convention No. 189 on decent work for domestic workers' (C189) in $2011^{4}$ and the creation of the International Domestic Workers Federation (IDWF-FITH) in 2012, which has been promoting the global campaign for the ratification of $\mathrm{C} 189$ since its founding. ${ }^{5}$ These key events have variously affected different national contexts, where international standards and global 
campaigns on the issue have been received, appropriated, or resisted in different ways by institutional and non-institutional actors, including domestic workers' organisations (Cherubini, Garofalo Geymonat, and Marchetti 2018).

In Ecuador and Colombia, paid domestic work has become an object of increasing attention from both institutional and non-institutional actors in the last decade. During the late 2000s and the 2010s, newly emergent mobilisations in the field have led to the creation or strengthening of paid domestic workers' organisations and to pivotal legislative reforms (among them, the ratification of $\mathrm{C} 189$ ) that are regarded as special achievements of these movements. As we will later discuss, these achievements have been possible partly thanks to the support of institutional actors, as well as national and international NGOs, that have recognised C189 as a strategic opportunity for achieving their goals and have integrated this exogenous factor, its logic and language, into their actions. In general terms, we can say that the struggles for domestic workers' rights have been favoured by the progressive politics in both countries in the last decade, related in Ecuador to Rafael Correa's administration (2007-2017) and in Colombia to the end of the war and subsequent peace process (since 2012). Under these conditions, we see the expansion of rights for domestic workers as part of larger political projects working towards a more egalitarian society and the inclusion of historically marginalised groups as essential to the formation of a renewed national identity (Marchetti 2018).

Other relevant similarities between the two countries have to do with the main characteristics and the composition of the domestic workforce. According to the latest available data, around 681,000 people were employed as domestic workers in Colombia in 2017 and 214,000 in Ecuador in 2018, representing three percent of all workers in both countries. ${ }^{6}$ Qualitative accounts collected in interviews with key informants in both countries describe domestic work as a highly feminised sector, mainly employing women from lower social classes and with low educational levels, often coming from the most impoverished regions of the countries, and whose working conditions vary greatly according to their age, ethnicity, and rural or urban residence. Our interviewees agree that the majority of paid domestic workers are Colombian or Ecuadorian nationals, although international migrants from other Latin American countries are also present and include, notably, Colombian refugees and Peruvian migrants in Ecuador, and, more recently, Venezuelan refugees in both countries.

An analysis of quantitative data helps to refine this description. Data show, first, how in both countries internal movements from rural to urban areas and from poor to rich regions - as well as, for the case of Colombia, from the regions most affected by internal war - have long determined the current composition of this workforce. ${ }^{7}$ They also show how the composition of this workforce reflects the ethnic and racial diversity of these countries - a key feature of their social stratification and national identity, categorised in terms of relations between 'white,' 'mestiza,' 'black/Afro-descendant,' and 'indigenous' populations. ${ }^{8}$ Finally, in both countries domestic workers are more likely to be women, aged over 30, and with a low level of education. ${ }^{9}$ 
To sum up, Colombia and Ecuador show relevant similarities when it comes to the legal frame regulating domestic worker's labour rights, recent trends in domestic workers' organising, and in the composition of the sector, which appears to be fundamentally shaped by internal migrations, ethnic and racial diversity, and gender-race-class relations rooted in colonial legacy. Despite specific differences that will become clear in the analysis that follows, we are confronted with two national contexts that can be considered as a comparable background for the analysis of the identity and activities of the two selected domestic workers' organisations, which we will discuss in the following sections.

\section{The Ecuadorian Domestic Workers Association (ATHE) ${ }^{10}$}

ATHE was created in the late 1990s in one of the country's largest cities. ${ }^{11}$ It mostly operated at the local level until the mid-2000s, when it expanded its activities and visibility beyond its province of origin and started to articulate claims at a national scale, focusing upon the transformation of the legal and policy frameworks regulating domestic work.

\section{I 'We are all domestic workers': gender and class in the construction of collective identity}

Since its creation, ATHE has been not only composed but also led by women who work or have worked for many years as domestic workers. According to the narratives these leaders offered in interviews and at public events, ATHE articulates the specific interests and identity of the 'trabajadoras remuneradas de hogar,' meaning the (women employed as) domestic workers. From analysis of the interviews, it can be seen that the term serves to describe a type of labour and a social category created by the interplay between two main dimensions of inequality: gender and class position. Indeed, according to ATHE leaders, the specific form of oppression lived by domestic workers seems to be rooted in the gendered and classist construction of (paid and unpaid) domestic work. The idea of reproductive work as a female responsibility and its social, economic, and symbolic devaluation are portrayed as strongly related, and the dominant representation of domestic work as a job for women from lower social classes is reflected in the lack of both labour rights and social respect. For instance, one of the leaders of the association explains the following:

The social classes that we come from, we are low social classes, whether black, white, indigenous, mestizo or whatever. . . . It is a hard job, it is not recognized, rights are always violated, here we can see the patriarchal system . . . that women in general are considered . . . just because you are a woman, you must be related to reproduction.

(ECU04, ATHE leader) 
Along this line of analysis, ATHE leaders seem to think that domestic workers' struggles for labour rights cannot be considered as similar to those of other workers or to be related to the 'universal' interests of the working class. Likewise, the way in which gender, in its interplay with class, applies to the case of domestic workers is understood as significantly different from what happens in the case of other women and other female workers. For this reason, rather than general unions, women's and feminist groups, or gender equality bodies, it is necessary that ad hoc organisations with the specific purpose of addressing the problems of domestic workers are set up. This discourse seems to indicate that the organising process leading to the formation of ATHE may be exemplary of practices of political subjectification that domestic workers activate in reacting to their intersectional marginalisation, at the structural and political levels, through collective action and through the construction of a 'multiple-axes' organisation. This echoes the ethos of 'organising on one's own' described by Benita Roth (2004) in relation to black and chicana feminisms in the United States, as well as what Éléonore Lépinard (2014) has called 'intersectional representation,' defined as one of the possible ways of practicing intersectionality in social movements.

The quote above also shows the specific construction of race differences within ATHE's discourse and collective identity. The organisation presents itself as being inclusive of and representing the interests of all domestic workers, no matter the sector of society they belong to, and in particular, their racial and ethnic background. In other words, while the intersection between class and gender receives most of the political emphasis in the self-representation developed by ATHE leaders, the same cannot be said of other intersections between categories of difference such as race/ethnicity, age, and migration status. On these other issues, the organisation offers a more variegated approach, according to the situation and the level of action. In fact, although forms of discrimination based on race, gender, age, and nationality are often mentioned and denounced by leaders during the interviews and in their internal activities, they are granted less relevance in the formulation of claims directed to external actors, as we explain in the following section.

\subsection{ATHE actions and claims}

On the issue of racism, those who suffer from discrimination in paid domestic work are the compañeras of Esmeralda, ${ }^{12}$ the afros. . . . The compañeras who are indigenous, too.... Somehow it affects us, because you should put yourself in the other's shoes. For example, in training and empowerment. ... In fact, we had to work on the strengthening of recognizing ourselves as a woman, as an afro, as a mestiza, as an indigenous woman. Definitely we have worked on these aspects, yes.

(ECU08, ATHE leader)

These words from another leader of the association exemplify the way in which different forms of racial discrimination - intertwined in this case with gender-based 
discrimination - are addressed in internal activities acting for the empowerment of members (e.g. information and training). Through these internal activities ATHE explicitly addresses the risk of discrimination, exploitation, violence, and abusive behaviour from employers to which specifically Afro-Ecuadorian, indigenous, or migrant domestic workers are exposed to. At the same time, the narrative quoted above implicitly recognises the relative privilege that mestizas domestic workers may have, in comparison to domestic workers belonging to other racialised social groups. At this level of action ATHE promotes an intersectional understanding encompassing domestic workers' social position, their possible pathways toward empowerment, and the power asymmetries within their own group.

However, such intersectional awareness with respect to race issues seems to be set aside when it comes to activities directed towards external actors, such as those aimed at influencing government interventions, for example to improve the legal framework for the sector, or to alter the public image of 'domestic work as work.' In this case, the interests and needs of specific sub-groups of domestic workers are subsumed into the general struggle for equality between domestic workers and other workers both in the legal and in the cultural field. In our interpretation, this level of ATHE action with regard to ethnic, racial, and other differences can be understood as a case of an additive or 'multiple' approach (Hancock 2007). In other words, race-based discriminations are seen as an additional burden worsening the condition of racialised domestic workers, but not as an intrinsic feature of the social organisation of domestic work.

\section{3 'Yo apoyo al Convenio 189, y tu?' Campaigning and strengthening alliances in the labour field}

The framing processes described so far emerge more clearly in considering the campaign for the ratification of $\mathrm{C} 189$ run by ATHE and its allies from 2011 to 2013. After the promulgation of the convention in Geneva in June 2011, a committee for ratification was formed in Ecuador and the campaign 'Yo apoyo al Convenio 189, y tu?' ('I support Convention 189, and you?') was launched. The campaign developed through a series of awareness-raising interventions in public spaces and in the media and through the participation of technical and political working groups within state institutions and the government, in particular in the Ministries of Labor and Social Security. Key actors on the committee were ATHE, two international NGOs that are long-term allies of ATHE, and other international organisations (including the local office of the ILO). The support of individual policymakers from the governmental party Alianza Paìs also proved crucial to this phase, especially in preparing the debate in the National Assembly and creating a large consensus for the ratification, which crossed all political groups. In September 2013, the ratification was approved unanimously by the National Assembly. ATHE and other supporters attended the debate as audience members wore yellow t-shirts with the campaign logoas did the supportive parliamentarians in their stalls. 
The ratification of $\mathrm{C} 189$ was portrayed by informants from ATHE as a strategic objective in order to consolidate their position as workers on an equal footing with other workers. The claim for 'equal rights and decent work,' which is central to C189, brings together the ideals of labour equality and human dignity in order to promote the inclusion of domestic workers in the general labour force on equal grounds. In the context of ATHE's interventions, the support for C189 was framed in relation to the need for a new cultural and economic approach to the role of domestic workers in society, considered primarily as a category of vulnerable and discriminated workers.

Within this framework, C189 claims provided an opportunity for the convergence of the organization's objectives and governmental politics relating to labour and class equality. C189 was portrayed as giving expression to the ideals of equality, social progress, and modernisation that, notwithstanding existing limitations, the Correa government fiercely proclaimed to be in the national interest. According to some key informants, the ratification of $\mathrm{C} 189$ represented the 'cherry on top' of a period of legal reforms originating with the constitutional process.

ATHE and the Correa government both aimed at the full integration of domestic work into the general labour code, removing all existing normative bias and legislative exceptions concerning minimum wage, working hours, social security coverage, and unionisation rights. In the words of a congresswoman supportive of the campaign:

The recognition of workers has always been there in Correa's discourse, and this included women domestic workers. . . . For that reason before the approval of Convention 189, the government of the Republic implemented a public policy. .., to put (domestic workers) on the same level of other workers. ... What the Convention did, was simply ... it was like the cherry on top: and the public policy made much earlier was the cake

(ECU14, congresswoman and feminist activist)

These words align with a similar stance on the part of ATHE representatives, as in the following statement:

Well, I think that we have had this progress in recent years ... Now, with the Revolución Ciudadana, ${ }^{13}$ we achieved at least the unified basic salary, which domestic workers are also entitled to, like any other worker.

(ECU08, ATHE leader)

In observing the campaign for ratification, the advantages of having such a sharply defined agenda in the field of labour rights are evident. These are, firstly, the capacity to formulate pragmatic objectives and, secondly, the possibility of establishing long-term alliances. In fact, the synergy and alignment between ATHE, international NGOs, and the government led to the successful ratification of C189 and to other key achievements in the legal field, which established full 
equal labour rights for domestic workers in Ecuador. However, pursuing such a sharply defined agenda appears to have come at the cost of simplifying the intersectional approach that ATHE developed in their internal actions and claims. However, rather than constituting a 'failure' or lack of ability to put intersectionality into practice, this may represent a strategic reading of the political situation, on the part of ATHE, and its need to find common ground with potential allies, particularly with the government.

\section{The Colombian Domestic Workers Union (UTDC)}

UTDC was founded in the early 2010s in one of the largest cities in Colombia by a group of Afro-Colombian domestic workers - most of them internal war refugees. At the time of our fieldwork (2018), the organisation had gathered around 200 members and was one of the most visible domestic workers' associations in the country.

\section{I 'The first ethnic-based domestic workers' union of the country': collective identity and interests between gender, class, and race}

Similar to what we have described in relation to ATHE, UTDC can be considered an example of organising which responds to an 'intersectional representation' strategy (Lépinard 2014), through which a social group subjected to social and political marginalisation organises on their own (Roth 2004) and creates a new collective actor representing its own voice and interests. In the case of UTDC, however, the element of race is integrated into the collective identity and enters, along with class and gender, in the analysis of domestic workers' conditions developed by the organisation. Domestic work is addressed not solely as a gendered but also as a racialised sector; the specific experiences of gendered racism and racialised economic exploitation lived by Afro-Colombian women employed as domestic workers are recognised and lead to the construction of what the activists describe as 'the first ethnic-based domestic workers' union of the country,' as their website clearly states.

UTDC openly relies on an intersectional discursive repertoire based on the articulation of gender, class, and race - where the dimension of race and racism is mostly shaped around the experience of black women working in the sector - and, more specifically, the experience of internally displaced AfroColombian women. Other experiences of racism that are in place in domestic work and in Colombian society are discursively acknowledged by the leaders, for instance those lived by indigenous or migrant domestic workers. However, this does not lead to the articulation of specific claims for each of these subgroups. In fact, this is how one of the leaders describes the union's aims and organising process: 
This process [the organizing process that led to the creation of the UCDW] brought positive results for us as domestic workers ${ }^{14}$ and in particular, for black women, women victims of armed conflict, displaced women, female heads of households, abused women, raped women, discriminated women, women who have gone, as domestic workers, through all kind of things that this country cannot even imagine. And why have we arrived at domestic work? Because we are not asked 'what do you know? What is your (job) experience?' But the color, the race, this marks me in a way that I have to be a domestic worker, to clean floors, to mop and to be in that place, only for this color. However, UTDC is an inclusive, not exclusionary, union; even if its name says Afro women, there are mestizas and indigenous women in the union ... The advocacy is not only for Afro women, women from Antioquia or Chocó ${ }^{15} \ldots$ We do this for the benefit of all women nationwide.

(COL03, UTDC leader)

As this excerpt suggests, UTDC leaders present the union as being at the same time rooted in the black and Afro-descendant identity and open to all domestic workers - black, mestizas, and indigenous - and concerned simultaneously with the end of racist discrimination against Afro-Colombian women and with the advancement of labour rights for all domestic workers. In other words, they present the organisation as representative of both the specific interests of black domestic workers and the general interests of the category of labourers. This kind of articulation of collective identity within the union should be framed in the broader political context, characterised by a long-term trend towards the re-integration of historically marginalised ethnic communities (among them, Afro-Colombians) within the national identity since the 1991 constitution, by restorative policies targeting displaced people (most of them belonging to the black minority) deployed by state and civic society actors, and by the rising awareness of women's rights and the conditions of racial minorities, in the context of the peace process. Within this framework, C189 provided opportunities for a renewed politicisation of paid domestic workers' rights, after decades of low mobilisation and low visibility due to the internal war, political violence, and the repression of social and labour movements.

\subsection{UTDC actions and claims}

The objective of UTDC, its desire, its aspiration is that all . . first of all, to show the government and society that we are here in this world, we are present, we are domestic workers women, that we also have the same value, the same rights as other workers. ... God, we have to raise the alarm to the government, the State, that here we are domestic workers, that we also exist and that we also are Colombian. ... Our message? Domestic workers [feminine form used] give value to your work and do not wait for others to do that, do it right but give it the right price too. The point is, I do my job well and I demand decent 
treatment, because domestic work is not a favor, domestic work, as Convention 189 states, is work. It is like the nurse, like the professor, the gardener, domestic work is a job and a profession.

(COL03, UTDC leader)

This quotation from the interview with a UTDC leader exemplifies the main claims of the organisation, which aims at transforming the conditions of domestic workers with respect to the economic and cultural terrain and at fostering their recognition as part of the Colombian society, economy, and national identity. According to our observations and interviews, the union pursues these objectives both through training and sensitising activities directed towards its members and through political pressure targeting state institutions in order to improve the legal frame regulating domestic workers' labour rights.

Similar to what we described in the Ecuadorian case, the internal activities seem to draw on a complex and intersectional reading of the reality and needs of domestic workers, whose pathways towards empowerment encompass the overcoming of multiple processes of marginalisation and require the reconstruction of a positive self-image.

For instance, within the actions that we do internally, we do training in gender equality, we do training in labor rights, ethnic training, these are the activities we have designed and that we emphasize, because we know that on the issue of gender equality ... all this inequality for being a woman . . . and it is not the same to be a woman, in Colombia, and to be a black woman, neither the same to be a black woman as to be a poor woman, so . . . all this makes the difference, it makes everything harder. . . . We also have sexual and reproductive education workshops, that are very important because as women, all these things are going to help us, because we cannot go on with this mindset that black women are just there to give birth and to work in a house ... So all those programs are designed with our characteristics in mind.

(COL03, UTDC leader)

What happens at the level of the activities directed towards external and institutional actors is, once again, quite different. As with ATHE, the central goal is the achievement of equal labour rights. However, as we will show in the next section, UTDC articulates the struggle in the labour field in a unique manner, in which feminist discourse converges with the field of action of the care economy.

\subsection{The Ley de Prima campaign: convergence between domestic workers' rights and feminist views on the value of care}

UTDC began its activities when the main issue at stake for domestic workers' struggles was the implementation of $\mathrm{C} 189$ - which had earlier been ratified by 
the government without major opposition - and the transformation of the legal frame regulating labour rights and access to social security for domestic workers, in compliance with the principle set by the convention. In fact, Colombia ratified C189 in 2012 (Law 1595 of 2012) ) $^{16}$ and thereafter adopted a number of measures that included this category of workers within the social security system (Decree 2616 of 2013 expanding access to social security to 'per days' domestic workers; Decree 721 giving access to family benefits). In this frame, UTDC engaged in its first and most relevant campaign, for the so-called Ley de Prima (Law on Bonus).

The campaign started at the end of 2013 and was promoted by UTDC in alliance with two non-profit organisations providing technical support to UTDC activities since its creation - one involved in the labour field and another in the promotion of social communication, well-being, and education - and with two feminist congresswomen from the Green Party who played a key role in the process. The building of this coalition was facilitated by the fact that during the same period these UTDC allies were also involved in a feminist debate on the value of reproductive work and on the so-called care economy (Folbre 2001; Boris and Parreňas 2010; Lutz 2011) and in the Comité para la Economía del Cuidado (Care Economy Committee), ${ }^{17}$ a space for planning and negotiation composed of institutional and non-institutional actors created in 2010. The campaign developed through several public events, communication interventions in traditional media and social networks, and lobbying activities. It culminated in parliamentary debates through which the law was finally approved in June 2016 (Law 1788).

The law extended the right to receive the 'prima de servicio' (that is, the thirteenth check given to all workers in 'productive' sectors) to domestic workers, who were previously excluded from such provision. Notably in this case, the argument at the centre of this historical exclusion - the fact that (paid and unpaid) domestic work does not produce any profit, in other words it is reproductive as opposed to productive - was overturned through this campaign, drawing on feminist debates around the value of care. In fact, since the late 2000 s, feminist groups and individuals - most of them coming from the academy and public sector institutions - were promoting a debate on the care economy in Colombia. One of their main achievements was the National Law on the Care Economy approved in 2010 (Law 1413 of 2010), which gives full recognition to the social and economic value of unpaid care and domestic work and lays the basis for its financial and economic measurement in official statistics, as part of the national GDP. UTDC and the other actors campaigning for the bonus used these tools for making the value of paid domestic work visible. This in turn opened the possibility of correcting what domestic workers and their allies reframed as discrimination of a valuable category of workers who actively contribute to the national economy and to Colombian society. This is how the spokesperson of one of the allied NGOs and participant in the Committee describes the process:

Definitely in recent years the care economy is what has given the feminist movement the figures that economists require when making public 
policies ... I can tell you that in almost all the more or less serious discussions and analyses on the matter of gender equality, in Colombia we can make use of the figures coming from sectors of the Care Economy, and in this way the discussion is among peers; before it was a bit romantic and abstract.

(COL18, member of an NGO supporting UTDC)

Therefore, the campaign developed by UTDC may be seen as an example of convergence between domestic workers' struggle for labour rights and feminist struggles for the transformation of the socio-cultural representation of reproductive work and recognition of the value of women's work and of their contribution to the economy and society. In the Colombian case, the legal and discursive frame on the social and economic value of reproductive work has transformed into one which is favourable to domestic workers' struggles, even if it was primarily related to unpaid work performed by women for their families. By stretching the original scope of the care economy framework to include paid work, UTDC has revealed - and challenged - the epistemic and institutional privileges embedded in the social organisation of care and domestic work, exposing the problematic assumptions present in the division between paid/unpaid, skilled/unskilled, and productive/reproductive labour.

\section{Discussion}

Both organisations studied in the present chapter, ATHE and UTDC, since their creation, have been composed and led by women employed as domestic workers, who have reacted to the lack of rights and social recognition experienced by their category in society at large as well as to the situation of political marginalisation they live in institutional politics, in the local civil society, and within existing social movements. According to our analysis, both organisations exemplify processes of political subjectification and organising that come from multiplymarginalised groups and lead to the construction of 'multiple-axis' organisations, to complex collective identities, and to forms of intersectional praxis. Yet, the kinds of intersectional politics developed by the two organisations diverge in relation to several aspects, namely (a) in relation to the categories and experiences of inequality that are emphasised in the building of collective identity and in the pursuit of inclusivity and unity and (b) in their alliances with other actors.

First, we have seen that the two organisations define the specific form of marginalisation lived by domestic workers differently, as resulting from 'intersectional' or 'multiple/additive' relations between different sources of inequality. According to our analysis of the self-presentation of the leaders of the two organisations, the Colombian organisation appears to propose an intersectional understanding of the interplay between gender, class, and race in shaping domestic workers' experience of discrimination, while the Ecuadorian organisation points out the intersectional relationship between class and gender, but is less keen to identify the intersection with race as constitutive of their subordinated condition. ATHE sees race-based 
discrimination as something that contributes to increased levels of exploitation suffered by non-white and not-mestiza domestic workers, but they do not make this into a central feature of their collective identity, thus maintaining an 'additive/multiple' approach to racism and racial difference. Second, we have seen that both organisations portray themselves as representing the interests of all domestic workers, but they rely on different arguments to sustain this claim. ATHE purports to be inclusive of all domestic workers despite ethnic and racial differences: its strategy consists of transcending such differences in order to include the needs of all categories of domestic workers into its general struggle. By contrast, UTDC claims to represent the interests of the entire category (including white and indigenous workers) on the ground of racial differences: since Afro-Colombians are 'the ones who suffer the most,' i.e. the most stigmatised and vulnerable group, they can embrace the perspective of all other vulnerable groups. Moreover, we have shown that the two organisations have different strategies in their campaigns in the field of labour rights and in establishing alliances with different types of actors: in Ecuador, the left-wing government that promotes favourable politics towards the working class, and in Colombia the feminist movement engaged in the debate on the social and economic value of care work. Last, we have seen how, in the Colombian case, such an alliance entails a challenge to the epistemic and institutional privileges often present in the care economy discourse mobilised by feminist actors. Indeed, the alliance produced around the campaign for the Ley de Prima was able to overcome the initial exclusive focus on unpaid reproductive work that feminists had developed, by exposing how it problematically reproduces the divisions between women based on class and race.

Conversely, the analysis of the claims and actions carried out by the two organisations has shown relevant similarities. Importantly, we have seen that, while complex and intersectional views seem to inform the internal activities of both organisations, when it comes to the campaigns and lobby activities directed at external actors, they seem to adopt a rather simplified (often quite unitary, singleaxis) strategy, mostly focused on labour issues. This apparent move towards the simplification of the issues at stake may be understood as a result of the convergence between actors' strategic choices and the opportunities given to them in a specific setting. Notably, the adoption of simplified claims in the organisations' lobbying activity and campaigns should not obscure the relevance of intersectional orientation and practices at other levels of their activity and collective identity.

\section{Conclusion}

In this chapter, domestic workers' movements are seen as forms of collective action developed by the multiply-marginalised social groups employed in the sector such as migrant, low-class, racialised, and rural women. We have shown how domestic workers' mobilisations may offer a space where several usually separated social struggles converge, such as those for equal labour rights and class equity, women's rights, and recognition for ethnic and racialised minorities. At the 
same time, the regulation of domestic work is a contentious issue, able to reveal conflicting interests and power asymmetries based on gender, class, race, and so on. For these reasons, the analysis of these movements allowed us to look at how the intersections of gender, class, race, ethnicity, and other relevant categories in each context are enfolded in, and in turn shape, the processes taking place within these movements, their identity-making activities, their strategies and actions, and their alliances.

Overall the results of our analysis show how, when using intersectionality as an analytical tool, it is particularly important to unpack the various aspects involved in the mobilisation process, such as collective identity, elaboration of agenda and claims, strategies and actions, and alliances and conflict with other actors, in order to avoid assuming a spontaneous coherence between the different levels of analysis. As our case studies reflect, intersectionality might emerge as a key element in some moments of a mobilisation process, while being a marginal one in others. For instance, it may be present in the discourse produced by the movement but not reflected in its action; it may be a central issue in some campaigns and not in others; it may shape the movement's composition but not its claims; it may be a central concern in members' recruitment but not be reflected in alliances built with other movements, and so on. Movements' strategies and positioning with respect to this terrain may change when moving from one field of action to another (for example between the separate fields of labour rights, anti-racism, and human rights), from one scale to another (such as local, national, and transnational organising), as well as over time - depending on both the power relations affecting the field and the strategic choices of the movements. Moreover, in distinct aspects and moments of their activity, social movements may address some forms of inequality, some intersections between social categories and social groups, while silencing or failing to address some others. The meaning and political salience assigned to gender, race, class, and other social categories vary not only between different national contexts and in different domestic workers' organisations, but also within the same organisation in relation to different aspects of its activity.

\section{Notes}

1 The present chapter is the result of the authors' shared analyses and writing. Daniela Cherubini is the author of sections 2 and 5, Giulia Garofalo Geymonat is the author of sections 1 and 6, Sabrina Marchetti is the author of sections 3 and 4. This publication has received funding from the European Research Council (ERC) under the European Union's Horizon 2020 Research and Innovation Programme, under Grant Agreement n. 678783 (DomEQUAL). Principal Investigator Prof. Sabrina Marchetti, Ca' Foscari University of Venice. www.domequal.eu.

2 We thank our country experts Gabriela Alvarado Perez (Ecuador) and Maria Fernanda Cepeda Anaya (Colombia) for their contribution to gathering data for our analysis.

3 The names of these organisations have been modified to ensure the anonymity of participants.

4 Convention No. 189 and the relative Recommendation No. 201 set international labour standards for the paid care and domestic work sector, equating labour rights for these 
workers to those of other workers in ratifying countries. At the time of writing 25 countries in the world have already ratified the convention. www.ilo.org/dyn/normlex/en/f?p= NORMLEXPUB:11300:0::NO::P11300_INSTRUMENT_ID:2551460 [accessed 31 October 2018].

5 From webpage information at http://idwfed.org/en/campaigns/ratify-c189 [accessed 31 October 2018].

6 Data are taken from the Gran Encuesta Integrada de Hogares of the Departamento Administrativo Nacional de Estadistica (Colombia) and the Encuesta Nacional de Empleo, Desempleo y Subempleo of the Instituto Nacional de Estadística y Censos (Ecuador).

7 According to available census data, in Colombia (2005) 41 percent of domestic workers were internal migrants and/or refugees. In the regions of Bogotá, Valle del Cauca, and Antioquia - where four out of ten domestic workers were employed, most of them in the cities of Bogotá, Cali, and Medellin - this percentage stood at 87 percent, 57 percent, and 23 percent respectively. Similarly, in Ecuador (2010) internal migrants represented 31 percent of the domestic workforce. These shares peaked at 56 percent and 44 percent in Pichincha and Guayas, two provinces that alone host more than half (56 percent) of domestic workers living in the country, most of them in the main cities of Quito and Guayaquil. In both countries internal migrants (or refugees) are counted as those who work in a region or province other than their birth region/province.

8 In Colombia the vast majority of domestic workers define themselves as 'white' (85\%), followed by 'black' $(12 \%)$, and 'indigenous' (3\%); similar percentages are found in the total population $(85 \%, 10 \%$, and $3 \%$ respectively). In Ecuador domestic workers are 'mestizas' (69\%), 'montubias' (7.6\%), Afro-Ecuadorian (7\%), 'indigenous' (6\%) and 'white' (5\%). Afro-Ecuadorian people are overrepresented in domestic work (accounting for $7 \%$ vs. $4 \%$ among all workers), while other groups account for similar percentages in domestic work and in the total population.

9 Women represent 95 percent of domestic workers (vs. 50 percent of 'all workers') in Ecuador and 91 percent (vs. 51 percent of 'all workers') in Colombia. Of those, 84 percent have an educational level lower than secondary school vs. 72 percent of 'all workers' in Ecuador; 81 percent vs. 74 percent of 'all workers' in Colombia.

10 Names of the organisations have been modified to ensure the anonymity of participants.

11 Name removed to ensure anonymity.

12 One of the regions with a large Afro-descendant population, from which many internal migrants come and are employed as domestic workers in the main cities.

13 The Citizens' Revolution, the political and socio-economic project at the basis of Rafael Correa's government and the 2008 Constitution.

14 'Trabajadoras domésticas' in the original. The feminine form is used throughout the sentence.

15 The region with the highest percentage of black and Afro-Colombian groups (75.68\%); also one of the poorest regions of the country.

16 The Convention entered into force in 2014.

17 Fictional name.

\section{References}

Alberti, Gabriella, Jane Holgate, and Matie Tapia. 2013. "Organising Migrants as Workers or as Migrant Workers? Intersectionality, Trade Unions and Precarious Work.” The International Journal of Human Resource Management 24 (22): 4132-4148.

Anthias, Floya. 2012. "Hierarchies of Social Location, Class and Intersectionality: Towards a Translocational Frame." International Sociology 28 (1): 121-138. 
Bassel, Leah, and Éléonore Lépinard. 2014. "Introduction.” Politics \& Gender 10 (1): $115-117$.

Bernardino-Costa, Joaze. 2014. 'Intersectionality and Female Domestic Workers' Unions in Brazil." Women's Studies International Forum 46: 72-80.

Boris, Eileen, and Jennifer N. Fish. 2014. “'Slaves No More': Making Global Labor Standards for Domestic Workers.” Feminist Studies 40 (2): 411-443.

Boris, Eileen, and Rhacel Salazar Parreňas. 2010. Intimate Labors: Cultures, Technologies, and the Politics of Care. Stanford, CA: Stanford University Press.

Carastathis, Anna. 2013. "Identity Categories as Potential Coalitions." Signs 38 (4): 941-965.

Cherubini, Daniela, Giulia Garofalo Geymonat, and Sabrina Marchetti. 2018. "Global Rights and Local Struggles: The Case of the ILO Convention n. 189 on Domestic Work." Partecipazione e Conflitto 11 (3): 717-742.

Chun, Jennifer Jihye, George Lipsitz, and Young Shin. 2013. "Intersectionality as a Social Movement Strategy: Asian Immigrant Women Advocates.” Signs 38 (4): 917-940.

Cobble, Dorothy Sue. 2005. The Other Women's Movement: Workplace Justice and Social Rights in Modern America. Princeton, NJ: Princeton University Press.

Cole, Elizabeth. 2008. "Coalition as a Model for Intersectionality: From Practice to Theory.” Sex Roles 59 (5-6): 443-453.

Coley, Jonathan S. 2014. "Social Movements and Bridge Building: Religious and Sexual Identity Conflicts." In Intersectionality and Social Change, edited by Lynne. M. Woehrle, 125-151. Bingley, UK: Emerald.

Cruells López, Marta, and Sonia Ruiz García. 2014. "Political Intersectionality Within the Spanish Indignados Social Movement." In Intersectionality and Social Change, edited by Lynne M. Woehrle, 325. Bingley, UK: Emerald.

Evans, Elizabeth. 2016. "Intersectionality as a Feminist Praxis in the UK." Women's Studies International Forum 59: 67-75.

Ferree, Myra Marx, and Silke Roth. 1998. "Gender, Class and the Interaction Between Social Movements: A Strike of West Berlin Day Care Workers." Gender and Society 12 (6): 626-648.

Fish, Jennifer. N. 2017. Domestic Workers of the World Unite! A Global Movement for Dignity and Human Rights. New York, NY: New York University Press.

Folbre, Nancy. 2001. The Invisible Heart: Economics and Family Values. New York, NY: New Press.

Hancock, Ange-Marie. 2007. “When Multiplication Doesn't Equal Quick Addition: Examining Intersectionality as a Research Paradigm.” Perspectives on Politics 5 (1): 63-79.

Lapèrriere, Marie, and Eléonore Lépinard. 2016. "Intersectionality as a Tool for Social Movements: Strategies of Inclusion and Representation in the Québécois Women's Movement." Politics 36 (4): 374-382.

Lépinard, Éléonore. 2014. "Doing Intersectionality: Repertoires of Feminist Practices in France and Canada." Gender \& Society 28 (6): 877-903.

Lutz, Helma. 2011. The New Maids: Transnational Women and the Care Economy. London: Zed Books.

Maddison, Sarah, and Emma Partridge. 2014. "Agonism and Intersectionality: Indigenous Women, Violence and Feminist Collective Identity." In Intersectionality and Social Change, edited by Lynne M. Woehrle, 27-52. Bingley, UK: Emerald.

Marchetti, Sabrina. 2018. "The Global Governance of Paid Domestic Work: Comparing the Impact of ILO Convention No. 189 in Ecuador and India." Critical Sociology 44 (7-8): 1191-1205. 
Marchetti, Sabrina, and Giulia Garofalo Geymonat, eds. 2017. Domestic Workers Speak: A Global Fight for Rights and Recognition. London: Open Democracy.

Molyneux, Maxine.2001. Women's Movements in International Perspective: Latin America and Beyond. London: Springer.

Okechukwu, Amaka. 2014. "Shadows of Solidarity: Identity, Intersectionality, and Frame Resonance." In Intersectionality and Social Change, edited by Lynne M. Woehrle, 153180. Bingley, UK: Emerald.

Predelli, Line Nyhagen, and Beatrice Halsaa, eds. 2012. Majority-Minority Relations in Contemporary Women's Movements: Strategic Sisterhood. Houndmills, Basingstoke: Palgrave Macmillan.

Roth, Benita. 2004. Separate Roads to Feminism: Black, Chicana, and White Feminist Movements in America's Second Wave. Cambridge, UK: Cambridge University Press.

Rothman, Jay. 2014. "From Intragroup Conflict to Intergroup Cooperation." In Intersectionality and Social Change, edited by Lynne M. Woehrle, 107-123. Bingley, UK: Emerald.

Sarti, Raffaella. 2007. "The Globalisation of Domestic Service in a Historical Perspective." In Migration and Domestic Work: A European Perspective on a Global Theme, edited by Helma Lutz, 77-98. Aldershot: Ashgate.

Schwenken, Helen 2016. "The Emergence of an Impossible Movement: Domestic Workers Organize Globally.” In Transnational Struggles for Recognition: New Perspectives on Civil Society Since the 20th Century, edited by Dieter Gosewinkel and Dieter Rucht, 205228. New York, NY: Berghahn Books.

Strolovitch, Dara Z. 2007. Affirmative Advocacy: Race, Class, and Gender in Interest Group Politics. Chicago, IL: University of Chicago Press.

Townsend-Bell, Erica. 2011. "What Is Relevance? Defining Intersectional Praxis in Uruguay." Political Research Quarterly 64 (1): 187-199.

Verloo, Mieke. 2013. "Intersectional and Cross-Movement Politics and Policies: Reflection on Current Practices and Debates.” Signs 38 (4): 1893-8915.

Yuval-Davis, Nira. 2015. "Situated Intersectionality and Social Inequality." Raisons Politiques 2: 91-100. 